\title{
Color and odor of artificial fruit used to signal potential dispersers in the Atlantic forest in Brazil
}

\author{
Aliny Oliveira Barcelos ${ }^{1}$, Clayton Perônico² \& Frederico Jacob Eutrópio ${ }^{3}$ \\ 1. Universidade Vila Velha, Programa de Mestrado em Ecologia de Ecossistemas-Rua Comissário José Dantas de Melo, \\ 21, Boa Vista, Vila Velha, Espírito Santo, Brazil, CEP 29102-770; oliveira.aliny@ gmail.com \\ 2. Instituto Federal do Espírito Santo - IFES campus Piúma - Rua Augusto Costa de Oliveira, 660, Praia Doce Piúma, \\ Espírito Santo, Brazil, CEP 29285-000; cperonico@ifes.edu.br \\ 3. Universidade Vila Velha, Programa de Doutorado em Ecologia de Ecossistemas-Rua Comissário José Dantas de Melo, \\ 21, Boa Vista, Vila Velha, Espírito Santo, Brazil, CEP 29102-770; eutropiofj@gmail.com
}

Received 09-V-2011. C Corrected 20-IX-2011. Accepted 19-X-2011.

\begin{abstract}
Fruit color and odor are the main features regulating the rate of fruit predation and dispersal. The aim of this study was to analyze the effect of odor and color on fruit predators and dispersers. The present study was conducted in a $30 \mathrm{ha}$ area of secondary forest in Southeastern Atlantic Brazil. This area was divided into two transects, in which four points were marked with a $30 \mathrm{~m}$ distance from each other. Each sampling point contained a total of 30 artificial fruit which belong to six different treatment groups, with five artificial fruit per group. Each group was randomly placed on the ground and that artificial fruit was checked every seven days. For each group of five fruit, $5 \mathrm{~mL}$ of essence (vanilla or pineapple) were placed, and no essence was used in the control group. Artificial fruit was made with green and red nontoxic modeling clay, as well as artificial essences (vanilla and pineapple). A total of 960 fruits were used. Predated fruit equaled 26.9\% (258 units), from which the red/pineapple had the highest predation rate $(81.9 \%)$, followed by red/vanilla $(46.3 \%)$, while green/control fruits were not predated. Throughout the experiment, bitten fruit and pecked fruit equaled $58.3 \%$ and $41.7 \%$, respectively. No significant differences were recorded $\left(\mathrm{x}^{2}=7.57, \mathrm{df}=5, \mathrm{p}=0.182\right)$ between bitten and pecked fruit. Fruit color and odor are important in attracting predators and dispersers, which explains the high rate of predation of red/ vanilla and red/pineapple, and the absence of predated fruits in the green/control group. Regarding the potential disperser, there was no statistically significant difference between pecked fruit and bitten fruit. As a result, it should be taken into consideration that zoochory (mammalochory and ornithochory) is the most important dispersal; therefore, it should be concluded that birds are more attracted by color and mammals by odor. Rev. Biol. Trop. 60 (2): 925-931. Epub 2012 June 01.
\end{abstract}

Key words: frugivory, mammalochory, ornithochory, plant-animal interaction, predation, seed dispersal, zoochory.

In plant communities, the dispersal syndrome deserves special mention, because of the strong dependence of plants on dispersers (Lomáscolo \& Schaefer 2010). The survival of a species depends on seed dispersal and a suitable place for germination. In tropical forests, the most frequent dispersal syndrome found is zoochory, i.e. fruits are eaten and dispersed by animals. Mammalochory, dispersal by mammals, and ornithochory, dispersal by birds, are also found. It is estimated that between $50 \%$ and $90 \%$ of tree species depend on this type of dispersal (Howe \& Smallwood 1982, Janson 1983, Fleming 1987, Tabarelli \& Peres 2002, Galetti et al. 2003).

The main characteristics that regulate the predation rate of different groups of animals include fruit size, color, odor, consistency, quantity and nutritional quality (Gautier-Hion et al. 1985, Galetti et al. 2003, Cáceres et al. 
2009). This causes fruits to develop a large number of strategies and special characteristics to attract consumer-dispersing species (Arruda et al. 2008). Among these characteristics, color and odor have shown to be important fruit detection attributes for predators (Schmidt et al. 2004, Lomáscolo et al. 2008). However, the contrast between fruit color and its background had never been included in any study on dispersal syndromes (Lomáscolo \& Schaefer 2010).

Few studies have recently examined the direct effect of fruit odor and color, or the interaction between these factors, upon the rate of removal and/or predation by different consumer groups. This study aimed to test the effect of fruit odor and color on the predation rate, as well as to relate it to the different groups of predators/dispersers.

\section{MATERIALS AND METHODS}

Study site: The Atlantic Forest is one of the most threatened ecosystems on the planet, retaining only $8 \%$ of its original area (Myers et al. 2000, Galindo-Leal \& Câmara 2005). The study was conducted in the municipality of Marechal Floriano, Espírito Santo State. The study area $\left(20^{\circ} 26^{\prime} 32^{\prime \prime} \mathrm{S}-40^{\circ} 464^{\prime} 4\right.$ " W) is located $720 \mathrm{~m}$ above sea level and covers $30 \mathrm{ha}$ of secondary Atlantic Forest, with 90 years of regeneration. In the Serra do Mar region, the Atlantic Forest has sub-humid climate, poor soil and high rainfall (Tabarelli et al. 2005).

Data collection: Four samples were taken between November 2009 and January 2010 with 15 day-intervals. Each sampling was conducted in two $100 \mathrm{~m}$ equidistant linear transects, parallel to the forest edge. Four sampling points were established for each transect, at 30m distance (Álvarez \& Galetti 2007). A total of 30 fruits with six randomly disposed treatments were arranged at each sampling point, i.e. five fruits per sample group. Artificial fruits were placed on the ground to analyze which ones remained visible after seven days and the types of animals that forage for them. New fruit was employed in each new sampling. Five milliliters of essence (vanilla or pineapple) were placed in each group of five fruits, and no essence was used for the control groups. Artificial fruit was made using $5 \mathrm{~g}(2 \mathrm{~cm}$ in diameter) of green and red starchy, nontoxic, odorless, water-resistant modeling clay, for a total of 960 artificial fruits by the end of the samplings (Arruda et al. 2008). Fruit was considered predated when it was moved from where it was placed.

Potential predators of artificial fruit were identified based on Alves-Costa \& Lopes (2001) and França \& Marini (2009), where "V" or "U" shapes characterized bird pecking and teeth marks characterized as mammalian bites. Disposable gloves were used at all times to avoid the interference of human odor on predators/dispersers' behavior.

Treatments were compared using Kruskal Wallis $(\mathrm{p}<0.05)$ and Tukey's nonparametric tests $(\mathrm{p}<0.05)$. Contingency tables (chi-square $\mathrm{p}<0.05$ ) were used to evaluate whether the number of artificial fruits pecked or bitten was the same for each one of the treatments (Zar 2008). Values of predated fruits per treatment were expressed as a mean and as standard deviation.

\section{RESULTS}

Of the 960 artificial fruits used in the experiment, 258 (26.9\%) were predated. Considering the predation rate on the artificial fruit per treatment, the red/pineapple treatment had the highest predation rate $(81.9 \%)$, followed by red/vanilla (46.3\%), while green/ control fruits were not predated (Table 1). The mean of fruit predation was higher with red/ pineapple $(4.1 \pm 0.78)$ followed by red/vanilla (2.3 \pm 0.47$)$ (Fig. 1).

Throughout the experiment, pecking $(41.7 \%)$ and bites $(58.3 \%)$ were recorded but no significant differences were detected $\left(x^{2}=7.57, g l=5, p=0.182\right)$. The red/control treatment registered only pecks, and for the green/ control treatment no predated fruits were found (Fig. 2 and 3). 
TABLE 1

Total number of fruits, predated fruits and predated fruit percentage for each color/odor treatment

\begin{tabular}{lccc}
\multicolumn{1}{c}{ Treatment } & Fruit $(\mathrm{N})$ & Predated fruit & Predated fruit $(\%)$ \\
Red/Pineapple & 160 & 131 & 81.9 \\
Red/Vanilla & 160 & 74 & 46.3 \\
Red/Control & 160 & 14 & 8.8 \\
Green/Pineapple & 160 & 34 & 21.3 \\
Green/Vanilla & 160 & 5 & 3.1 \\
Green/Control & 160 & 0 & 0 \\
\hline
\end{tabular}

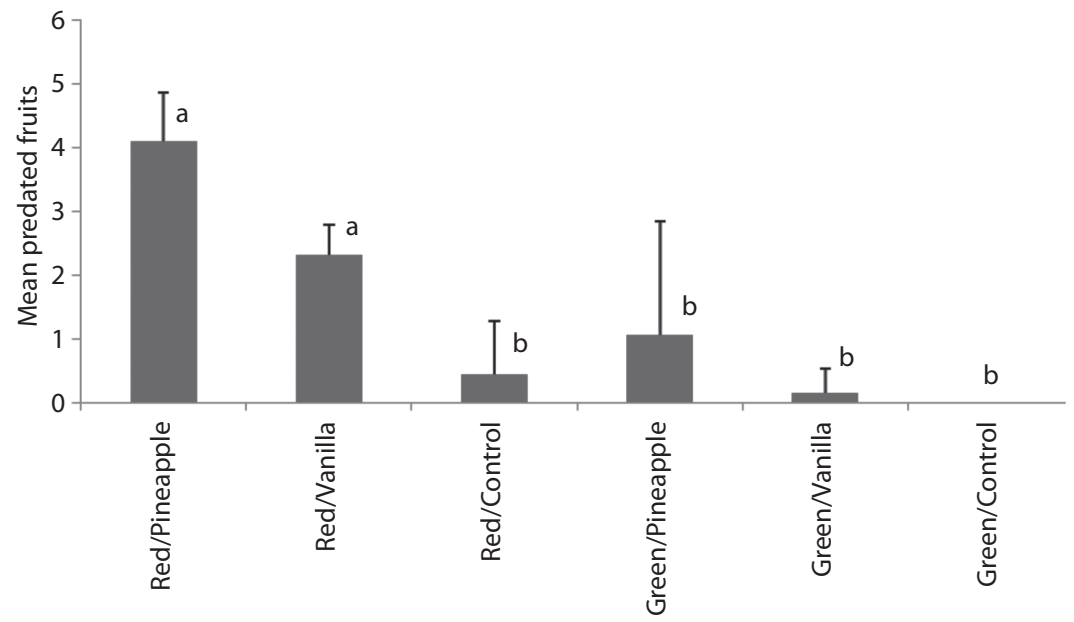

Fig. 1. Mean of predated fruits per color/odor treatment. Letters indicate significant differences between treatments using Kruskal Wallis and Tukey's tests $(\mathrm{p}<0.05)$.

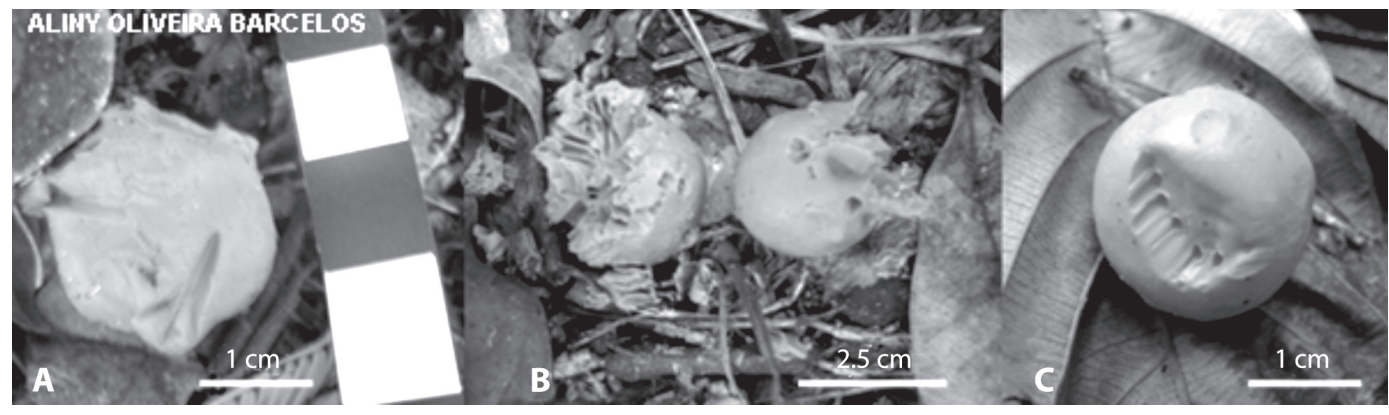

Fig. 2. Marks left by possible fruit predators: (A) Birds. (B) Mammals (rodents) and (C) Mammals. 


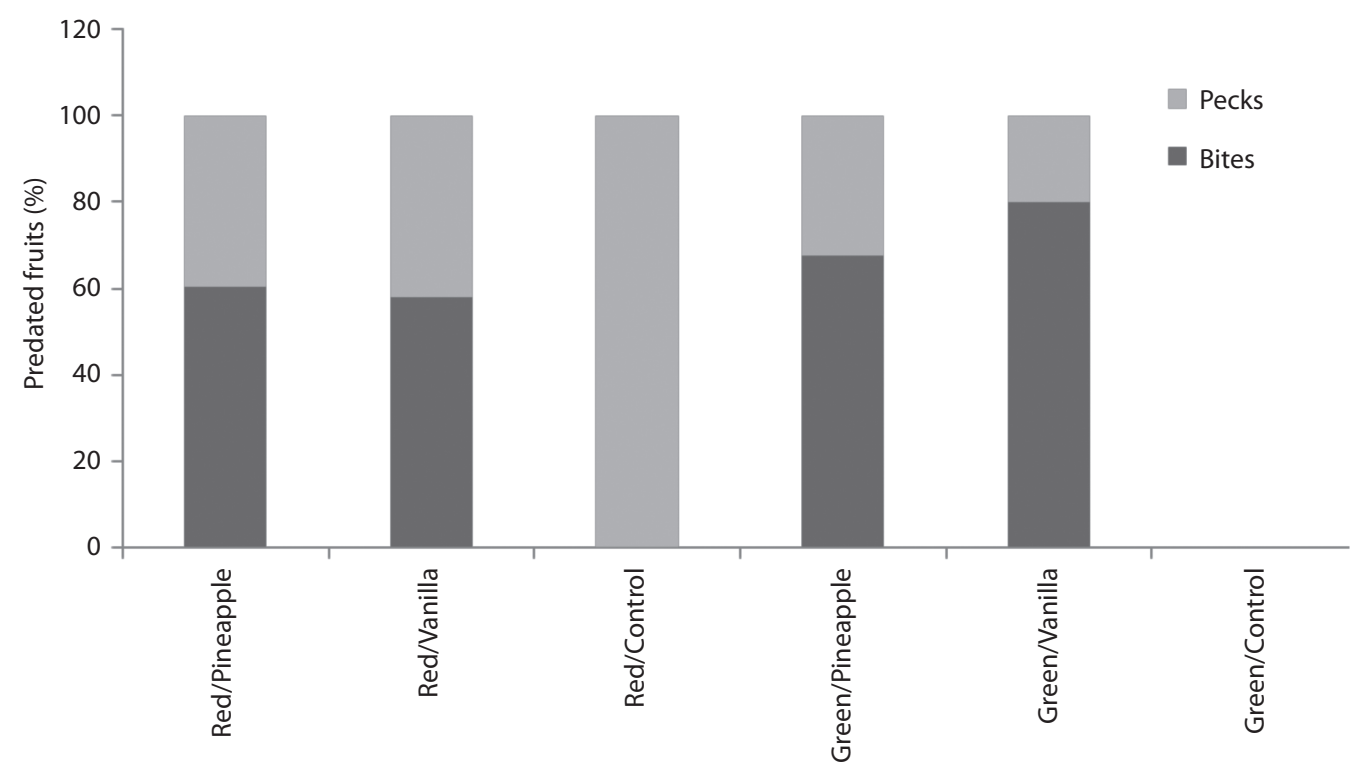

Fig. 3. Percentage of bites and pecks on predated fruit per color/odor treatment.

\section{DISCUSSION}

The results of this study show that fruits with red color were more frequently eaten by birds. This finding is in concordance with Arruda et al. (2008) who found that among the 263 pecked fruits $62.2 \%$ were red. In addition, studies in Peru and Costa Rica by Wheelwright \& Janson (1985) pointed out that $36 \%$ of the fruits pecked were red. This preference for red was also observed in the field by Gervais et al. (1999) and Alves-Costa \& Lopes (2001) and in captivity by McPherson (1988) and Willson et al. (1990). The cryptic color of fruit functions mainly to attract the attention of potential dispersers that use vision as the key sense to search for food, influencing the selective pressure by birds at foraging (Wheelwright \& Janson 1985, Willson et al. 1990, Arruda et al. 2008).

Burns \& Dalen (2002), Schmidt et al. (2004), Schaefer et al. (2006) and Schaefer et al. (2007) attribute birds' preference for red fruits to the contrast with the background foliage. Furthermore, the red color has a longer wavelength, more visible to birds than other colors (Arruda et al. 2008). However, according to Pizo (2003), some birds prey less attractive colors, such as green, for another type of dispersal; this was observed by Spironello et al. (2004) who registered 3910 unmoved fruits, that is, $0.5 \%$ was predated in an immature phase by parrots and rats.

The low predation rate of green fruit helps understand the co-evolution between plants and seed dispersers, where dispersed plants, mainly by ornithocoric means, have immature green fruits as a strategy to avoid dispersal of those that are not yet ready to germinate (Schaefer et al. 2007, Lomáscolo \& Schaefer 2010). For Burns et al. (2009) and Cazetta et al. (2007) fruit color is related to the detection of potential dispersers, and tropical regions generally have higher diversity of fruit color, as they have the highest number of seed dispersers due to the increased plant diversity. In addition, Burns et al. (2009) mention that the fruit color evolution hypothesis is not exclusively ascribed to the selection of potential seed dispersers, since there is no greater diversity of fruit color than 
in the tropics where coloration may be associated to the reflective properties of leaves.

Birds have good vision and hearing, but a poorly developed sense of smell, while mammals have a sharper sense of smell, but not good color definition, especially nocturnal species (Lomáscolo et al. 2008); therefore, according to Janson (1983), fruits eaten by nocturnal species are probably large and odorous. The results of this study indicating that $58.3 \%$ of fruit was bitten differed from those of Arruda et al. (2008), who reported $1.3 \%$ of the fruit being bitten. However, Arruda et al. (2008) did not use essences, which evidences smell as the main sense of orientation in mammals and confirms the work by Vieira et al. (2011) and Iob \& Vieira (2008), who used vanilla extract in traps to attract grid mammals having a high capture rate, these being rodents, followed by marsupials. Nevertheless, few studies have discussed mammalian odor attraction in the process of predation and dispersal of fruits.

Wheelwright \& Janson (1985) and Lomáscolo et al. (2008) reported that both color and odor in fruits are important in attracting predators and dispersers, which explains the high rate of predation of red/pineapple and red/vanilla and no predation of the green fruits of the control treatment group. The abundance of fruit, fruit predation rate and the presence of predator/disperser can be influenced by the size of the fragment, the edge effect (Galetti et al. 2003) and the regeneration state of the habitat (Tabarelli \& Peres 2002).

Treatments using essences showed a higher percentage of bitten fruit, while treatments with red color presented more pecking, although no significant differences were observed between pecked and bitten fruit, indicating that there is no preference between birds and mammals. For Gauthier-Hion et al. (1985), this dichotomy between fruit dispersed by birds or mammals is not strong, unlike aspects related to fruit size, protection or color. Consequently, it is not possible to specify the most effective potential disperser of a plant species, only based on morphological characteristics of the fruit.
Regarding the potential disperser, no statistically significant differences were found between pecked fruit and bitten fruit, which clearly suggests that both birds and mammals are potential fruit dispersers, thus, indispensable elements in the dynamics of communities, spatial distribution of plants, and structure and restoration of degraded areas. The foregoing confirms that zoochory (both mammalochory and ornithochory) is the main dispersal method, although, in general, birds are more attracted by color and mammals by odor. The use of artificial fruit is a good study tool to analyze potential dispersers that allows for the identification of species. This corroborates Arruda et al. (2008), who confirmed that artificial fruits are effective to record fruit consumption, assist in the identification of potential dispersers, and are easy to handle in the field.

In order to specifically determine the disperser of a plant, further studies should be conducted related to fruit color, size, nutritional value and position, as well as animal characteristics and fragment size, edge effects, species composition and plant regeneration time.

\section{ACKNOWLEDGMENTS}

We would like to thank Cesar Abel Krohling for his help during fieldwork and his support on the logistics and Dominik Lenz and Elieth Salazar for editing the English.

\section{RESUMEN}

El olor y el color de los frutos son las características principales que regulan el nivel de consumo y la dispersión de las semillas. Este estudio tuvo como objetivo analizar el efecto que tiene el olor y el color de los frutos sobre los depredadores y dispersores de semillas. El área de estudio abarca 30ha de bosque secundario localizado en el Atlántico sureste de Brasil. Este espacio se dividió en dos sectores, en los cuales se marcaron cuatro puntos con una distancia de 30m entre sí. En cada punto de muestreo se utilizaron 30 frutos que se distribuyeron en seis tratamientos, con cinco frutos artificiales para cada tratamiento. Además, cabe resaltar que cada tratamiento se colocó en el suelo de forma aleatoria y que los frutos artificiales se verificaron cada siete días. Para cada grupo de cinco frutos se utilizaron $5 \mathrm{~mL}$ de esencia (vainilla y ananá) y para el grupo de 
control no se utilizó ningún aditivo de olor. Los frutos se confeccionaron con plastilina atóxica de color verde y roja, además de esencias artificiales (ananá y vainilla), asimismo se obtuvieron 960 frutos. El nivel de frutos consumidos fue del 26.9\% (258 unidades), de los cuales los rojos/ananá fueron los más consumidos (81.9\%), seguidos del rojo/ vainilla $(46.3 \%)$, mientras que los verde/control no fueron comidos. Durante el experimento la tasa de frutos mordidos fue del $58.3 \%$ y de picoteados un $41.7 \%$. No se registró una diferencia significativa $\left(\mathrm{x}^{2}=7.57, \mathrm{gl}=5, \mathrm{p}=0.182\right)$ entre frutos mordidos y picoteados. El color y el olor de los frutos son aspectos importantes para atraer depredadores y dispersores, lo que explica los niveles de consumo de los frutos rojos/vainilla y rojo/ananá y la ausencia de frutos comidos en el tratamiento del verde/control. En cuanto al potencial dispersor, no hubo una diferencia estadística significativa entre frutos mordidos y picoteados, por lo que se debe tomar en cuenta que la dispersión principal es la zoocoria (ornitocoria y mamalocoria). Por lo tanto, se puede concluir que las aves son atraídas por el color y los mamíferos por el olor.

Palabras clave: frugivoría, mamalocoria, ornitocoria, interacción planta-animal, depredación, dispersión de semillas, zoocoria.

\section{REFERENCES}

Álvarez, A.D. \& M. Galetti. 2007. Predação de ninhos artificiais em uma ilha na Mata Atlântica: testando o local e o tipo de ovo. Rev. Bras. Zool. 24: 1011-1016.

Alves-Costa, C.P. \& A.V. Lopes. 2001. Using artificial fruits to evaluate fruit selection by birds in the field. Biotropica 33: 713-717.

Arruda, R., D.J. Rodrigues \& T.J. Izzo. 2008. Rapid assessment of fruit-color selection by birds using artificial fruits at local scale in Central Amazonia. Acta. Amaz. 38: 291-296.

Burns, K.C., E. Cazetta, M. Galetti, A. Valido \& H.M. Schaefer. 2009. Geographic patterns in fruit colour diversity: do leaves constrain the colour of fleshy fruits? Oecologia 159: 337-343.

Burns, K.C. \& J.L. Dalen. 2002. Foliage color contrasts and adaptive fruit color variation in a bird-dispersed plant community. Oikos 96: 463-469.

Cáceres, N.C., L.Z. Prates, I.R. Ghizoni Jr \& M.E. Graipel. 2009. Frugivory by the black-eared opossum Didelphis aurita in the Atlantic Forest of southern Brazil: Roles of sex, season and sympatric species. Biotemas 22: 203-211.
Cazetta E., H.M. Schaefer \& M. Galetti. 2007. Why are fruits colorful? The relative importance of achromatic and chromatic contrasts for detection by birds. Evol. Ecol. 23: 233-244.

Fleming, T.H. 1987. Patterns of tropical vertebrate frugivore diversity. Annu. Rev. Ecol. Systemat. 18: 91-109.

França, L.C. \& A.Â. Marini. 2009. Teste do efeito de borda na predação de ninhos naturais e artificiais no Cerrado. Zoologia 26: 241-250.

Galetti, M., C.P. Alves-Costa \& E. Cazetta. 2003. Effects of forest fragmentation, antropogenic edges and fruit color on the consumption of ornithocoric fruits. Biol. Conservat. 111: 269-273.

Galindo-Leal, C. \& I.G. Câmara. 2005. Mata Atlântica: biodiversidade, ameaças e perspectivas. São Paulo: Fundação SOS Mata Atlântica - Belo Horizonte, Brazil.

Gautier-Hion, A., J.M. Duplantier, R. Quris, F. Feer, C. Sourd, J.P. Decoux, G. Dubost, L. Emmons, C. Erard, P. Hecketsweiler, A. Moungazi, C. Roussilhon \& J.M. Thiollay. 1985. Fruit characteristics as basis of fruit choice and seed dispersal in a tropical forest vertebrate community. Oecologia 65: 324-337.

Gervais, J.A., B.R. Noon \& M.F. Willson. 1999. Avian selection of the color-dimorphic fruits of salmonberry, Rubus spectabilis: a field experiment. Oikos 84: $77-86$.

Howe, H.F. \& J. Smallwood. 1982. Ecology of seed dispersal. Annu. Rev. Ecol. Systemat. 13: 201-228.

Iob, G. \& E.M. Vieira. 2008. Seed predation of Araucaria angustifolia (Araucariaceae) in the Brazilian Araucaria Forest: influence of deposition site and comparative role of small and large mammals. Plant. Ecol. 198: 185-196.

Janson, C.H. 1983. Adaptation of fruit morphology to dispersal agents in a Neotropical Forest. Science 219: 187-189.

Lomáscolo, S.B. \& H.M. Schaefer. 2010. Signal convergence in fruits: a result of selection by frugivores? J. Evol. Biol. 23: 614-624.

Lomáscolo, S.B., P. Speranza \& R.T. Kimball. 2008. Correlated evolution of fig size and color supports the dispersal syndromes hypothesis. Oecologia 156: 783-796.

McPherson, J.M. 1988. Preferences of cedar waxwings in the laboratory for fruit species, colour and size: 
a comparison with field observations. Anim. Behav. 36: 961-969.

Myers, N., R.A. Mittermeier, C.G. Mittermeier, G.A.B Fonseca \& J. Kent. 2000. Biodiversity hotspots for conservation priorities. Nature 403: 853-858.

Pizo, M.A. 2003. Padrão de deposição de sementes e sobrevivência de sementes e plântulas de duas espécies de Myrtaceae na Mata Atlântica. Rev. Bras. Bot. 26 371-377.

Schaefer, H.M., D.J. Levey, V. Schaefer \& M.L. Avery. 2006. The role of chromatic and achromatic signals for fruit detection by birds. Behav. Ecol. 17: 784-789.

Schaefer, H.M., V. Schaefer \& M. Vorobyev. 2007. Are Fruit Colors Adapted to Consumer Vision and Birds Equally Efficient in Detecting Colorful Signals? Am. Nat. 169: 159-169.

Schmidt, V., H.M. Schaefer \& H. Winkler. 2004. Conspicuousness, not colour as foraging cue in plant-animal signalling. Oikos 106: 551-557.

Spironello, W.R., P.T.B. Sampaio \& B. Ronchin-Teles. 2004. Produção e predação de frutos em Aniba rosaeodora Ducke var. amazônia Ducke (Lauraceae) em sistema de plantio sob floresta de terra firme na Amazônia Central. Acta Bot. Bras. 18: 801-807.

Tabarelli, M. \& C.A. Peres. 2002. Abiotic and vertebrate seed dispersal in the Brazilian Atlantic forest: implications for forest regeneration. Biol. Conservat. 106: 165-176.

Tabarelli, M., L.P. Pinto, J.M.C. Silva, M.M. Hirota \& L.C. Bedê. 2005. Desafios e oportunidades para a conservação na Mata Atlântica brasileira. Megadiveraidade 1: $132-138$

Vieira, E.M., J.F. Ribeiro \& G. Iob. 2011. Seed predation of Araucaria angustifolia (Araucariaceae) by small rodents in two areas with contrasting seed densities in the Brazilian Araucaria forest. J. Nat. Hist. 45: 843-854.

Wheelwright, N.T. \& C.H. Janson. 1985. Color of fruit displays of bird-dispersed plants in two tropical forests. Am. Nat. 126: 777-799.

Willson, M.F., D.A. Graff \& C.J. Whelan. 1990. Color preferences of frugivorous birds in relation to the colors of fleshy fruits. Condor 92: 545-555.

Zar, J.H. 2008. Biostatistical Analysis. Prentice-Hall, New Jersey, USA. 
